\title{
Coal's true cost
}

\author{
The deaths of birds have become a rallying point against the proliferation of wind farms. Yet the loss of \\ human life in mines is rarely linked with coal as an energy source.
}

In October 2010, millions watched as 33 Chilean miners were winched to safety after spending 69 days trapped underground in a copper and gold mine. Just a few days later, but half a world away, 37 Chinese coal miners were killed by an explosion. By all accounts, the Chinese miners never had the chance to reach an emergency shelter such as the one that protected their Chilean colleagues. Such safety precautions are few and far between in China's mix of state-run, private and illegal coal mines. Coal mine disasters are not limited to countries with lax regulations: 2010 saw an unusually lethal incident in which 29 coal miners lost their lives in a coal mine in West Virginia, USA. And that same year, New Zealand lost 29 workers to a series of explosions in the Pike River coal mine.

Despite these numbers, the media rarely make the connection between coal as a means of power generation and the risk of working in the mines. The desirability of wind power, by contrast, is frequently discussed in the context of its negative impacts on birds and bats (see, for example, http://nyti.ms/hBzndT). Wind turbines are erected in areas with strong, constant winds - areas that often coincide with the paths of migratory birds. Unfortunately, collisions between birds and rotor blades are usually fatal. As a result, the groups that lead the fight to reduce carbon emissions can easily find themselves leading the charge against wind power, too. Dead birds seem to evoke a stronger response than dead miners.

Renewable energies are apparently held to a higher standard. Because they are thought of as an environmentally friendly energy source, wind farms disappoint as soon as they are not perfectly innocuous. They do not receive the understanding and leeway usually granted to industrial-scale power plants - to look ugly, to generate noise or to bear risks for the environment. Perhaps it is time to place bird fatalities in the context of other power sources.

No known source of energy is without some risk of collateral damage. One need not look further than the Deepwater Horizon explosion and spill to see the potential costs in oil recovery. The crises at several nuclear reactors in Japan following the earthquake and tsunami in March 2011 have shown that nuclear power plants are no match for the forces of nature. Solar panels generally rely on the supply of rare Earth elements; mining of these ores tends to leave behind a slightly radioactive slurry of mine tailings, and their refinement relies on powerful, toxic acids. And large-scale dams such as the Three Gorges dam in
China are criticised for dramatically altering river hydrology, sediment characteristics and ecosystems.

Yet the world's energy demands soar. According to the US Energy Information Administration (http://www.eia.doe. gov/oiaf/ieo/coal.html), coal-derived power accounts for $27 \%$ of world energy production, and coal consumption is projected to grow by $56 \%$ by 2035 . Scrubber technology is creating coal-burning power plants that release fewer pollutants. Add in carbon capture and storage technology, and coal might have the potential to become a relatively cheap and abundant energy source with a minimal carbon footprint. It may even help to fuel transport (Nature Geosci. 2, 818-820; 2009).

Coal has slowly begun to shed its association with the smog and pollution that blanketed cities such as London decades ago. As a cleaner and greener image of coal emerges, perhaps the deaths of the miners, too, will come into sharper public focus. Whether or not that happens any time soon, we need a more integrated approach to deciding how much risk - to the lives of humans and birds, to ecosystems and to the planet's climate we are willing to accept in return for energy availability.

\section{Tweets on Earth}

\section{Nature Geoscience has joined Twitter. We share our take on exciting developments in the Earth and planetary sciences as they happen.}

Scientific publishing has traditionally favoured careful checking over speed, and detailed explanations over brevity. But the world of the twenty-first century demands updates between weekly online publication dates, and a Research Highlight of 150 words is no longer deemed the smallest useful piece of scientific information. We at Nature Geoscience have decided to embrace the widening of the traditional range in both frequency and length.

Twitter allows us draw attention to geoscience-related stories as we encounter them, in ways that traditional publication pathways do not. In our Twitter stream we are highlighting articles that have piqued our interest from journals as well as newspapers. Twitter also gives us an outlet to respond to current events: for example, we have closely followed the March earthquake and tsunami in Japan and its impacts as events have unfolded. Finally, we are alerting our followers to the latest papers, opinion pieces and Review articles published in Nature Geoscience.
For those of our readers who are not on Twitter, nothing will change: we remain committed to publishing carefully peerreviewed papers, weekly online and monthly in our print and online full issues. For those who are signed up, we offer our perspective on current affairs related to the geosciences, in short snippets and real time.

We hope to entertain as much as to inform, and extend an open invitation to scientists and anyone interested in the Earth and planets to follow us. 